\title{
PENGARUH KUALITAS PELAYANAN TERHADAP KEPUASAN PASIEN PADA RUMAH SAKIT SARI ASIH DI WILAYAH CIAMIS
}

\author{
${ }^{1 *}$ Saptaning Ruju Paminto, ${ }^{2}$ Endah Lisarini, ${ }^{3} \mathrm{Hasbu}$ Naim Syaddad, \\ ${ }^{4}$ Dudung Amadung Abdullah \\ Universitas Suryakancana, Cianjur, Jawa Barat, Indonesia \\ *saptaning@unsur.ac.id
}

\begin{abstract}
Abstrak
Penelitian ini bertujuan untuk mengetahui pengaruh Kualitas Pelayanan terhadap Kepuasan Pasien pada Rumah Sakit Sari Asih di Wilayah Ciamis. Metode yang digunakan adalah explanatory research dengan sampel sebanyak 96 responden. Teknik analisis menggunakan analisis statistik dengan pengujian regresi, korelasi, determinasi dan uji hipotesis. Hasil penelitian ini variabel Kualitas Pelayanan diperoleh rata-rata skor sebesar 3,409 dengan kriteria baik. Variabel Kepuasan Pasien diperoleh rata-rata skor sebesar 3,831 dengan kriteria baik. Kualitas Pelayanan berpengaruh signifikan terhadap Kepuasan Pasien dengan persamaan regresi $Y=9,311+0,851 X$, dan nilai korelasi 0,774 atau kuat dengan determinasi 59,9\%. Uji hipotesis diperoleh signifikansi 0,000 <0,05.
\end{abstract}

Kata Kunci: Kualitas Pelayanan, Kepuasan Pasien.

\section{Abstract}

This study aims to determine the effect of Service Quality on Patient Satisfaction at Sari Asih Hospital in Ciamis Region. The method used is explanatory research with a sample of 96 respondents. The analysis technique uses statistical analysis with regression testing, correlation, determination and hypothesis testing. The results of this research variable Service Quality obtained an average score of 3.409 with good criteria. Patient Satisfaction Variable obtained an average score of 3,831 with good criteria. Service quality has a significant effect on patient satisfaction with the regression equation $Y=9.311+0.851 X$, and a correlation value of 0.774 or strong with a determination of 59.9\%. Hypothesis testing obtained a significance of $0.000<0.05$.

Keywords: Service Quality, Patient Satisfaction. 


\section{PENDAHULUAN}

Rumah sakit merupakan salah satu lembaga yang bergerak dalam bidang pelayanan dengan tanggung jawab memberikan pengobatan, memberikan perawatan, mengusahakan kesembuhan dan kesehatan pasien, serta mengupayakan pendidikan hidup sehat bagi masyarakat. Pengertian rumah sakit menurut Keputusan Menteri Kesehatan Republik Indonesia Nomor: 340/MEN/KES/PER/III/2010 disebutkan bahwa "Rumah sakit adalah institusi pelayanan kesehatan yang menyelenggarakan pelayanan kesehatan perorangan secara paripurna yang menyediakan pelayanan rawat inap, rawat jalan, dan gawat darurat". Dengan demikian rumah sakit merupakan suatu institusi yang memberikan pelayanan kesehatan pada semua bidang dan jenis penyakit. Kualitas pelayanan rumah sakit merupakan hal yang sangat penting sebagai acuan dalam pembenahan pelayanan sehingga tercipta suatu kepuasan pelanggan karena kepuasan merupakan konsep sentral dalam wacana bisnis manajemen.

Menurut Fajar Laksana (2008) berpendapat "Pelayanan merupakan tindakan atau kegiatan yang dapat di tawarkan kepada pihak lain, yang pada dasarnya tidak berwujud dan tidak mengakibatkan kepemilikan apapun". Pada saat ini industri jasa berusaha memberikan kualitas pelayanan yang baik untuk menarik pelanggan, maka dari itu kunci sukses bagi perusahaan jasa adalah pelayanan jasa yang baik dan tersedianya produk atau jasa yang dibutuhkan pelanggan juga peningkatan kualitas pelayanan baik.

Tindakan yang harus di prioritaskan oleh perusahaan dalam pasar bebas ini adalah kepuasan pelanggan, kepuasan pelanggan itu sendiri menurut Phillip Kotler (2012:42) ialah "Perasaan senang atau kecewa seseorang yang muncul setelah membandingkan antara persepsi atau kesannya terhadap kinerja atau hasil suatu produk/jasa atau harapan-harapannya".

Pemahaman terhadap pemenuhan keinginan pelanggan merupakan syarat peningkatan mutu dan produktifitas secara terus menerus dalam mencapai kepuasan total pelanggan. Pemenuhan keinginan pelanggan menjadi sangat penting dalam menentukan mutu pelayanan, Karena yang menentukan baik atau tidaknya mutu pelayanan bukanlah produsen atau perusahaan melainkan konsuman. Pelaksanaan pelayanan suatu perusahaan di bidang jasa adalah dengan memberikan kualitas pelayanan (service) yang terbaik dengan tujuan menciptakan kepuasan pelanggan. Dengan demikian kulitas pelayanan perusahaan dapat mengetahui apa saja yang perlu ditingkatkan atau diperbaiki untuk mencapai kebutuhan akan kepuasan pelanggan.

Banyaknya pilihan jasa yang tersedia membuat konsumen lebih cenderung menjatuhkan pilihan sesuai dengan persepsi mereka terhadap merek-merek tertentu yang menjadi favorit mereka. Perusahaan berlomba-lomba memperluas pangsa pasarnya, mencoba menarik pelanggan dengan cara mempengaruhi sikap konsumen agar bersedia memakai jasanya.

Rumah Sakit Sari Asih yang ada di wilayah Ciamis rata-rata termasuk rumah sakit ber-type B dan sudah terakreditasi penuh dengan 16 pelayanan lengkap dimana kota Bekasi yang merupakan penyangga ibu kota Jakarta menjadikan pangsa pasarnya adalah berbagai lapisan masyarakat.

Dalam upaya meningkatkan pelayanan kesehatan kepada masyarakat, RS. Sari Asih di Wilayah Ciamis sebagai salah satu rujukan pasien di wilayah Bekasi dan sekitarnya terus melakukan pembenahan. Hal ini sesuai dengan visinya, "Menjadi rumah sakit yang mampu memberikan pelayanan prima didukung oleh sumberdaya manusia yang profesional dan sejahtera, sarana prasarana yang memadai, serta manajemen yang dapat dipertanggung jawabkan. Dengan didukung tenaga dokter, perawat, pegawai khusus terapi, teknisi medis, kebidanan, pegawai khusus gizi, kefarmasian dan lain- 
lain dukungan. Adapun misinya yaitu: meningkatkan profesionalisme sumber daya manusia, meningkatkan kesejahteraan sumber daya manusia, mengembangkan sarana prasarana, mengembangkan manajemen pelayanan rumah sakit, serta memberikan pelayanan prima yang terjangkau dan didukung jaringan pelayanan kesehatan yang memadahi. Dengan didukung tenaga dokter, perawai, pegawai khusus terapi, teknisi medis, kebidanan, pegawai khusus gizi, kefarmasian serta fasilitas kelas VIP, I, II dan lain-lain menjadikan rumah sakit ini seharusnya mampu berkompetisi dengan rumah sakit lainnya.

Berdasarkan pemaparan di atas, maka penulis tertarik untuk melakukan penelitian dengan harapan dapat memberikan kontribusi yang positif dalam permasalahan yang timbul dan secara tepat dapat meningkatkan pelayanan yang maksimal kepada pelanggan. Adapun judul penelitian yang penulis lakukan adalah "Pengaruh Kualitas Pelayanan Terhadap Kepuasan Pasien Pada Rumah Sakit Sari Asih di Wilayah Ciamis".

\section{METODE PENELITIAN}

\section{Populasi}

Populasi dalam penelitian ini berjumlah 96 responden Rumah Sakit Sari Asih di Wilayah Ciamis

2. Sampel

Teknik pengambilan sampling dalam penelitian ini adalah samplel jenuh, dimana semua anggota populasi dijasikan sebagai sampel. Dengan demikian sampel dalam penelitian ini berjumlah 96 responden.

\section{Jenis Penelitian}

Jenis penelitian yang dipakai adalah asosiatif, dimana tujuannya adalah untuk mengetahui mencari keterhubungan antara variabel independen terhadap variabel dependennya

\section{Metode Analisis Data}

Dalam menganalisis data digunakan uji validitas, uji reliabilitas, analisis regresi linier sederhana, koefisien korelasi, koefisien determinasi dan uji hipotesis.

\section{HASIL PENELITIAN}

\section{Analisis Deskriptif}

Pada pengujian ini digunakan untuk mengetahui skor minimum dan maksimum skor tertinggi, ratting score dan standar deviasi dari masing-masing variabel. Adapun hasilnya sebagai berikut:

Tabel 1. Hasil Analisis Descriptive Statistics

Descriptive Statistics

$\mathrm{N}$ Minimum Maximum Mean Std. Deviation

\begin{tabular}{|l|r|r|r|r|r|r|}
\hline Kualitas Pelayanan (X) & 96 & 28 & 44 & 34.09 & 3.929 \\
\hline Kepuasan Pasien (Y) & 96 & 29 & 49 & 38.31 & 4.317 \\
\hline Valid N (listwise) & 96 & & & & \\
\hline
\end{tabular}

Kualitas Pelayanan diperoleh varians minimum sebesar 28 dan varians maximum 44 dengan ratting score sebesar 3,409 dengan standar deviasi 3,929.

Kepuasan Pasien diperoleh varians minimum sebesar 29 dan varians maximum 49 dengan ratting score sebesar 3,831 dengan standar deviasi 4,317.

\section{Analisis Verifikatif}

Pada analisis ini dimaksudkan untuk mengetahui pengaruh variabel independen terhadap variabel dependen. Adapun hasil pengujian sebagai berikut:

\section{a. Analisis Regresi Linier Sederhana}

Uji regresi ini dimaksudkan untuk mengetahui perubahan variabel dependen jika variabel independen mengalami perubahan. Adapun hasil pengujiannya sebagai berikut: 
Tabel 2. Hasil Pengujian Regresi Linier Sederhana Coefficients ${ }^{a}$

Unstandardized Standardized

\begin{tabular}{|c|c|c|c|c|c|c|}
\hline \multirow{2}{*}{\multicolumn{2}{|c|}{ Model }} & \multicolumn{2}{|c|}{ Coefficients } & \multirow{2}{*}{$\begin{array}{c}\text { Coefficients } \\
\text { Beta }\end{array}$} & \multirow[b]{2}{*}{$\mathrm{t}$} & \multirow[b]{2}{*}{ Sig. } \\
\hline & & B & Std. Error & & & \\
\hline 1 & (Constant) & 9.311 & 2.463 & & 3.781 & .000 \\
\hline & $\begin{array}{l}\text { Kualitas Pelayanan } \\
\text { (X) }\end{array}$ & .851 & .072 & .774 & 11.854 & .000 \\
\hline
\end{tabular}

a. Dependent Variable: Kepuasan Pasien (Y)

Berdasarkan hasil pengujian pada tabel di atas, diperoleh persamaan regresi $Y=9,311+0,851 X$. Dari persamaan tersebut dijelaskan sebagai berikut:

1) Konstanta sebesar 9,311 diartikan jika Kualitas Pelayanan dan motivasi tidak ada, maka telah terdapat nilai Kepuasan Pasien sebesar 9,311 point.

2) Koefisien regresi Kualitas Pelayanan sebesar 0,851, angka ini positif artinya setiap ada Tabel 3. Hasil Pengujian Koefisien Korelasi Kualitas Pelayanan Terhadap Kepuasan

Pasien.

Correlations $^{\mathrm{b}}$

Kualitas Pelayanan (X) $\mid$ Kepuasan Pasien (Y)

\begin{tabular}{llr|r}
\hline Kualitas Pelayanan $(X)$ & Pearson Correlation & 1 & $.774^{* *}$ \\
\cline { 2 - 4 } & Sig. (2-tailed) & & .000 \\
\hline Kepuasan Pasien (Y) & Pearson Correlation & $.774^{* *}$ & 1 \\
\cline { 2 - 4 } & Sig. (2-tailed) & .000 & \\
\hline
\end{tabular}

**. Correlation is significant at the 0.01 level (2-tailed).

b. Listwise $\mathrm{N}=96$
Berdasarkan hasil pengujian diperoleh nilai korelasi sebesar 0,774 artinya Kualitas Pelayanan memiliki hubungan yang kuat terhadap Kepuasan Pasien. peningkatan Kualitas Pelayanan sebesar 0,851 maka Kepuasan Pasien juga akan mengalami peningkatan sebesar 0,851 point.

\section{b. Analisis Koefisien Korelasi}

Analisis koefisien korelasi dimaksudkan untuk mengetahui tingkt kekuatan hubungan dari variabel independen terhadap variabel dependen baik secara parsial maupun simultan. Adapun hasil pengujian sebagai berikut: 


\section{d. Uji Hipotesis}

Pengujian hipotesis dengan uji $\mathrm{t}$ digunakan untuk mengetahui hipotesis mana yang diterima.

Tabel 5. Hasil Uji Hipotesis Kualitas Pelayanan Terhadap Kepuasan Pasien. Coefficients $^{a}$ Unstandardized Coefficients

\begin{tabular}{l|r|r|r|r|r}
\multicolumn{1}{l}{ Model } & \multicolumn{1}{c}{ B } & Std. Error & Beta & \multicolumn{1}{c}{$\mathrm{t}$} & Sig. \\
\hline 1 & 9.311 & 2.463 & & 3.781 & .000 \\
\hline $\begin{array}{l}\text { (Constant) } \\
\begin{array}{l}\text { Kualitas Pelayanan } \\
(X)\end{array}\end{array}$ & .851 & .072 & .774 & 11.854 & .000 \\
\hline
\end{tabular}

Rumusan hipotesis: Terdapat pengaruh yang signifikan Kualitas Pelayanan terhadap Kepuasan Pasien.

a. Dependent Variable: Kepuasan Pasien (Y)

Berdasarkan hasil pengujian pada tabel di atas, diperoleh nilai $\mathrm{t}$ hitung $>\mathrm{t}$ tabel atau $(11,654>1,986)$, dengan demikian hipotesis yang diajukan bahwa terdapat pengaruh yang signifikan atara Kualitas Pelayanan terhadap Kepuasan Pasien diterima.

\section{Pembahasan Hasil Penelitian}

\section{Kondisi Jawaban Responden Variabel} Kualitas Pelayanan

Berdasarkan jawaban responden, variabel Kualitas Pelayanan diperoleh ratting score sebesar 3,409 berada di rentang skala 3,409 - 4,19 dengan kriteria baik atau setuju.

\section{Kondisi Jawaban Responden Variabel Kepuasan Pasien}

Berdasarkan jawaban responden, variabel Kepuasan Pasien diperoleh ratting score sebesar 3,831 berada di rentang skala 3,409 - 4,19 dengan kriteria baik atau setuju.

\section{Pengaruh Kualitas Pelayanan Terhadap Kepuasan Pasien}

Kualitas Pelayanan berpengaruh signifikan terhadap Kepuasan Pasien dengan persamaan regresi $Y=17,517+$ $0,565 X$, nilai korelasi sebesar 0,774 atau memiliki hubungan yang kuat dengan kontribusi pengaruh sebesar 59,9\%. Pengujian hipotesis diperoleh nilai $t$ hitung $>\mathrm{t}$ tabel atau $(11,654>1,986)$. Dengan demikian hipotesis yang diajukan bahwa terdapat berpengaruh signifikan antara Kualitas Pelayanan terhadap Kepuasan Pasien diterima.

\section{PENUTUP}

Kesimpulan

a. Variabel Kualitas Pelayanan diperoleh ratting score sebesar 3,409 berada di rentang skala 3,409-4,19 dengan kriteria baik atau setuju.

b. Variabel Kepuasan Pasien diperoleh ratting score sebesar 3,831 berada di rentang skala 3,409-4,19 dengan kriteria baik atau setuju.

c. Kualitas Pelayanan berpengaruh signifikan terhadap Kepuasan Pasien dengan persamaan regresi $Y=17,517+$ $0,565 X$, nilai korelasi sebesar 0,774 atau kuat dan kontribusi pengaruh sebesar $59,9 \%$ sedangkan sisanya sebesar $40,1 \%$ dipengaruhi faktor lain. Uji hipotesis diperoleh nilai $\mathrm{t}$ hitung $>\mathrm{t}$ tabel atau $(11,654>1,986)$.

\section{Saran}

Berdasarkan kesimpulan hasil penelitian di atas, maka penulis memberikan saran sebagai berikut:

a. Kualitas pelayanan Rumah Sakit Sari Asih di Wilayah Ciamis harus lebih ditingkatkan lagi sehingga mencapai interpretasi sangat kuat pengaruhnya terhadap kepuasan, dengan demikian dapat menjaring pelanggan yang lebih banyak lagi.

b. Dewasa ini iklan melalui media elektronik terbukti cukup efektif dalam 
upaya menjaring pelanggan, oleh sebab itu perusahaan harus memikirkan strategi ini agar lebih dikenal masyarakat luas.

\section{DAFTAR PUSTAKA}

Algifari. (2015). “Analisis Regresi untuk Bisnis dan Ekonomi". Yogyakarta: BPFE.

Alma, Buchori. 2009. Manajemen Pemasaran $\mathcal{E}$ Pemasaran Jasa. Bandung: CV. Alfabetha.

Arikunto, Suharsimi (2014). "Prosedur Penelitian Suatu Pendekatan Praktek". Jakarta: Rineka Cipta.

Assauri, Sofian. 2008. Manajemen Produksi dan Operasi. Jakarta: LPFE Universitas Indonesia.

Erlangga, H. (2021). Effect Of Digital Marketing And Social Media On Purchase Intention Of Smes Food Products. Turkish Journal of Computer and Mathematics Education (TURCOMAT), 12(3), 3672-3678.

Erlangga, H., Sifatu, W. O., Wibisono, D., Siagian, A. O., Salam, R., \& Mas'adi, M. (2020). Pharmaceutical Business Competition in Indonesia: A Review. Systematic Reviews in Pharmacy, 11(10), 617-623.

Ferrinadewi, Erna. 2008. Merek Dan Psikologi Konsumen. Yogyakarta: Graha Ilmu,

Handi Irawan, "Prinsip Kepuasan Nasabah", Cetakan Kelima, Elex Media Komputindo, Jakarta, 2004.

Haque, M. G., Munawaroh, M., Sunarsi, D., \& Baharuddin, A. (2021). Competitive Advantage in Cost Leadership and Differentiation of SMEs "Bakoel Zee" Marketing Strategy in BSD. PINISI Discretion Review, 4(2), 277-284.

Hurriyati, Ratih, "Bauran Pemasaran Dan Loyalitas Konsumen", CV. Alfabetha, Bandung, 2010.

Imam Ghozali (2017). "Aplikasi Analisis Multivariate Dengan Program SPSS". Edisi Kelima. Semarang: Badan Penerbit Undip.

Istijanto (2014) “Riset Sumber Daya Manusia". Jakarta: PT. Gramedia Pustaka

Jasmani, J., \& Sunarsi, D. (2020). The
Influence of Product Mix, Promotion Mix and Brand Image on Consumer Purchasing Decisions of Sari Roti Products in South Tangerang. PINISI Discretion Review, 1(1), 165-174.

Julita. 2001. Menuju Kepuasan Pelanggan Melalui Penciptaan Kualitas Pelayanan. Jakarta: PT. Gramedia Pustaka.

Kasmad, K., Mustakim, M., \& Sunarsi, D. (2020). Increasing Community School Interest Through Service Quality, Prices and Promotion in Vocational High Schools. Journal of Educational Science and Technology (EST), 6(2).

Kasmir. 2010. Bank Dan Lembaga Keuangan Lainnya. Edisi Keenam. Jakarta: PT. Raja Grafindo Persada.

Keller dan Amstrong. 2008. Prinsip-Prinsip Pemasaran. Edisi Kedua Belas. Jilid Satu. Jakarta: Erlangga.

Kharis, Ismu Fadli (2011). "Studi Mengenai Impulse Buying dalam Penjualan Online". Semarang : Skripsi Universitas Diponegoro

Kotler, Phillip. 2009. Prinsip-prinsip Pemasaran. Edisi Kedua Belas, Jilid Satu, Jakarta: Erlangga.

Lovelock. 2007. Principle Of Services Marketing And Management", Prentice Hall Inc., Upper Saddle River, New Jersey.

Lupiyoadi. 2008. Manajemen Pemasaran Jasa. Jakarta: Salemba Empat.

Maddinsyah, A., Hidayat, D., Juhaeri, J., Susanto, D., \& Sunarsi, D. (2020). Desain Formulasi Dan Implementasi Bisnis Strategik Dengan Pendekatan Business Model Canvas (BMC) Terintegrasi Kerangka Integrated Performance Management System (IPMS) Pada Koperasi Asperindo. Inovasi, 7(2), 67-76.

Muslimat, A., Muhsin, H., Wahid, H. A., Yulistiana, I., Sunarsi, D., Dewi, K., ... \& Ilham, D. (2021). Develop Technology Based Multimedia For Indonesian Teachers. Journal of Contemporary Issues in Business and Government, 27(1), 1871-1882.

Purwanti, Y. (2021). The Influence Of Digital Marketing \& Innovasion On The 
School Performance. Turkish Journal of Computer and Mathematics Education (TURCOMAT), 12(7), 118127.

Muslimat, A. (2021). Masa Depan Kampus Merdeka \& Merdeka Belajar: Sebuah Bunga Rampai Dosen. Bintang Visitama Publisher.

Nurjaya, N., Affandi, A., Ilham, D., Jasmani, J., \& Sunarsi, D. (2021). Pengaruh Kompetensi Sumber Daya Manusia Dan Kemampuan Pemanfaatan Teknologi Terhadap Kinerja Aparatur Desa Pada Kantor Kepala Desa Di Kabupaten Gunungkidul, Yogyakarta. JENIUS (Jurnal Ilmiah Manajemen Sumber Daya Manusia), 4(3), 332-346.

Nurjaya, N., Affandi, A., Erlangga, H., Sunarsi, D., \& Jasmani, J. (2021). The Effect of Product Promotion and Innovation Activities on Marketing Performance in Middle Small Micro Enterprises in Cianjur. Budapest International Research and Critics Institute (BIRCI-Journal): Humanities and Social Sciences, 4(1), 528-540.

Peraturan Menteri Kesehatan Republik Indonesia Nomor: 340/MEN/KES/PER/III/2010

Tentang Tugas Dan Fungsi Rumah Sakit.

Purwanti, Y. (2021). The Influence Of Digital Marketing \& Innovasion On The School Performance. Turkish Journal of Computer and Mathematics Education (TURCOMAT), 12(7), 118-127.

Rao, Purba, (2012). "Measuring Consumer Perceptions Through Factor Analysis", The Asian.

Saladin, Djaslim. 2007. Manajemen Pemasaran. Bandung: Linda Karya.

Santoso, Singgih (2015). "Menguasai Statistik Multivariat". Jakarta: PT Elex Media Komputindo.
Sarwono, Jonathan. 2012. Metode Penelitian Kuantitatif Dan Kualitatif. Yogyakarta: Graha Ilmu.

Sudarsono, A., \& Sunarsi, D. (2020). Pengaruh Kualitas Pelayanan Dan Varian Produk Terhadap Keputusan Pembelian Pada Laboratorium Klinik Kimia Farma-Bintaro. Value: Jurnal Manajemen dan Akuntansi, 15(1), 16-26.

Sudjana (2014) "Metode Statistika", Bandung: Tarsido.

Sugiyono (2017), "Metode Penelitian Administrasi : dilengkapi dengan Metode $R \mathcal{E} D^{\prime \prime}$. Bandung: Alfabeta.

Suhartanto (2014). "Metode Riset Pemasaran". Bandung: Alfabeta

Supranto. 2008. Pengukuran Tingkat Kepuasan Pelanggan. Bogor: PT. Yudhistira.

Susanti, N., \& Jasmani, J. (2020). The Influence of Product Quality and Service Quality on Customer Satisfaction at Mitra 10 in Depok. Jurnal Office, 5(2), 75-84.

Swastha, Bashu dan T. Handoko. 2007. Manajemen Pemasaran. Edisi Pertama. Cetakan Ketiga. Yogyakarta: BPFE.

Syobar, K., Hardiyan, A., Romlah, O. Y., Yusup, M., \& Sunarsi, D. (2020). The Effect of Service Quality and Price on Purchase Decisions in Woodpecker Coffee in South Jakarta. Solid State Technology, 63(6), 1491-1504.

$\mathrm{T}$ Triyadi, U Ahidin, J Jasmani - Jurnal Manajemen, Bisnis dan Organisasi (JUMBO), 2019. Pengaruh Promosi Dan Kualitas Pelayanan Terhadap Kepuasan Pelanggan Pada PT. Surya Karya Prima Di Jakarta.

Tasunar, Nanang. 2006. Kualitas Pelayanan. Gramedia Pustaka Utama. Jakarta: , Ghalia Indonesia.

Tjiptono, Fandy. 2012. Pemasaran Jasa. Edisi Kedua. Malang : Bayu Media Publishing. 